The International Journal of the First Year in Higher Education ISSN: 1838-2959

Volume 3, Issue 2, pp. 59-64

August 2012

\title{
New horizons for vocational lecturers: Spreading the responsibility for transition. A Practice Report
}

Mark Smith

Unitec Institute of Technology, Auckland, New Zealand

\section{Abstract}

The transition of students into tertiary study at Unitec has often been seen as the responsibility of learning centres and student services, the domain of ex-language teachers and concerned counsellors, covered by social activities in orientation week and unmentioned for the remainder of the semester. This report describes an initiative to move transition into content areas by widening the horizons of vocational lecturers' view of what transition involves and indeed of what their discipline encompasses. It introduces a framework summarising some of the "first year experience" literature and discusses the implications it has for lecturers. The framework is four words - from, with, of, to - which cover the transition into tertiary study and on to graduation. Designed to be used by academic advisors with vocational lecturers at an Institute of Technology, the framework aims to spread responsibility for transition from support services onto the agendas of departments, programmes and teachers. It requires teachers to expand their horizons of tertiary education and transition.

Please cite this practice report as:

Smith, M. (2012). New horizons for vocational lecturers: Spreading the responsibility for transition. A Practice Report. The International Journal of the First Year in Higher Education, 3(2). 59-64. doi: 10.5204/intjfyhe.v3i2.129

This practice report has been accepted for publication in Int J FYHE. Please see the Editorial Policies under the 'About' section of the Journal website for further information.

(C) Copyright of practice reports is retained by authors. As an open access journal, articles are free to use, with proper attribution, in educational and other non-commercial settings. ISSN: 1838-2959 


\section{Introduction}

In 2011, Unitec Institute of Technology initiated an institute-wide strategy to improve the experience of students in their early engagements in tertiary education. This report describes one part of that initiative, the development of a framework for transition pedagogy, and its implications for lecturers. Traditionally, deliberate transitional activities at Unitec have been confined to orientations at the beginning of semesters. The framework is used by academic advisors and lecturers to extend transitional horizons, to address issues of transition and to discuss how solutions can be embedded in the curriculum and classroom.

At the end of 2010, a working party was set up to look at First Year Experiences at Unitec and to develop interventions to address issues around success, retention and progress. The working party, mindful of Kift, Nelson and Clarke's (2010) third generation approach to transition and Krause's (2006) list of common misconceptions about the first year, brought together representatives from all facets of the student experienceteaching, academic development, student well-being, the student association, marketing and school liaison. Various groups worked on a number of initiatives from communication with students through orientation week to identifying students at risk and peer mentoring. The transition pedagogy sub-group developed the framework described below, to be used by academic advisors in their conversations with lecturers. The framework is made up of four words-from, with, of, to-which attempt to capture the major elements of transition, provide a focus for conversation, and encourage questions and reflection on teaching, courses and programs.

\section{The framework - from-with-of-to}

\section{"From" - What are students' experiences? What do they bring to the classroom?}

Tertiary students are often accompanied by an adjective. No longer simply students, they are traditional or minority, mature or international, first-in-family, priority, working, part-time, EAL and in the New Zealand context, Maori or Pasifika ${ }^{1}$. Diversity, including socio-economic, ethnicity, age, gender and language, has become increasingly significant as tertiary education in New Zealand has moved away from an elite model. From recognises this diversity of experience and background and acknowledges that first year experiences are not homogenous. The route to tertiary study is more difficult for some because the transition process and preparation for tertiary begins well before any contact is made with an institution (Krause, 2006).

In reviewing the research on supporting students in tertiary study, Rivers (2005) supplements her ten propositions of how students can be integrated into a tertiary institution (these cover the students lifecycle from pre-enrolment advice and academic counselling through orientation to good teaching and the availability of supplemental instruction) with three propositions on institutional adaptation. These recognise the diversity of the tertiary population and posit that recognising, adapting to and catering to this diversity will enhance student outcomes.

\footnotetext{
1 Pasifika describes a diverse grouping of people from Pacific nation heritages living in New Zealand. With more Pasifika people born in New Zealand than overseas, 'Pasifika' are no longer an immigrant population. Retrieved from www.tec.govt.nz/.../TECPasifika-Strategy-2013-2016-DRAFT.pdf
} 
Bovill, Bulley and Morss' (2011) first point for an engaging and empowering curriculum mentions knowing student ability on entry, finding out their aims, goals (to in the language of the framework) and conflicting roles. Similarly in their analysis of key features from case studies, they list being inclusive of diversity, using students' own experiences as a focus for learning, listening to student voices and ensuring these views effect change (Bovill, Morss \& Bulley, 2008)

The diversity of students is not simply demographic. At a deeper and more important level are issues of ontology and epistemology-the beliefs students have about themselves, their identities and their beliefs about knowledge, teaching and learning. Green's (2007) review of the literature around student and teacher expectations and Gourlay's (2009) paper on threshold practices and academic literacies both make the point that transition into the new environment is fraught and difficult in no small part because it is so different from where the students are coming. This is more fully explored in defining the of, in the third part of the framework. However, as Kift et al. (2010) state, "in all their diversity, students come to higher education with the common and legitimate expectation of being provided with the opportunity and support to learn" (p. 7).

\section{"With" - creating a sense of belonging, orientating learners to place, centres and people}

The original preposition chosen for the framework was in, to capture the geographic location of students in a new space. However, while geography and familiarity with the campus are important elements of orientation, more important is orientation to people on campus-peers, teachers and support staff. Orientation week and activities aim to provide these connections but the with is academic as well as geographical and social. The with is about a sense of belonging both to the institution and to the chosen discipline.

A sense of connectedness assisting success is one of Wilson's (2009) themes: "We know that students on average are more likely to succeed if they [among other things] develop a social network" (p. 4). This is true for their relationships with their peers as much as their relationships with their teachers. In their report, Bovill et al. (2008) describe the features of an ideal first year curriculum (as described in the literature) as including orientation of students to increase social and academic engagement, and their connectedness to the university. Similarly, their analysis of their case studies includes both social networks and belonging to a learning community as important elements of early tertiary experiences. In summarising the research on the impact of student support services on student outcomes, Rivers (2005) notes that student outcomes are likely to be enhanced if there are opportunities for developing relationships with peers, teachers and services.

However, as Krause (2006) points out, the traditional orientation program may not be sufficient to make new students feel part of the place. "Transition is an ongoing process of developing an identity as a university student, of engaging with peers, staff and the university community" (p. 3). This brings us to the of.

\section{"Of" - developing an identity in the academic culture}

Orientation to the discipline is central to transition and is not a simple matter. It involves coming to terms with not only new content but also a change of identity. Of 
describes entry into a community with distinctive knowledge, practices and ways of enquiry which means engaging with threshold concepts, new literacies and epistemologies. A good starting point for the of is the situating of academic literacies by Lea and Street (1998) with their framework of academic skills, academic socialisation and academic literacies. They propose that we recognise the situated nature of learning and the ambivalence surrounding literacies and the reality of student identity in writing. Tinto (2009) suggests that we do not focus on how to retain students but ensure they acquire the disposition and skills to become effective learners at university; in our terms that they are of the university and the discipline.

Bovill et al.'s (2011) summary of the principles and guidelines for curriculum to engage and empower includes academic skills development throughout the program, engaging learning experiences and developing abilities for lifelong learning and work. Drawn from work done by Kift and Nelson, and Krause, it describes some of the requirements to assist students in the process of becoming part of the discipline and profession they have chosen.

A misconception of the of-ness which needs to be avoided is that it is simply about supporting students to acquire generic academic skills. For lecturers, the inclusion of of-ness requires a re-orientation away from content to acknowledging and making explicit elements of the curriculum which often lie below the surface. These include the enquiry nature of tertiary study, the centrality of literacies and language, threshold concepts and troublesome knowledge.

\section{"To" - where students are headed}

The to applies to various horizons, as much to the micro (course and level - where does this fit and what happens in my other course, my next semester/year?) as to macro (what happens when I graduate?). The graduate profile is one answer to to type questions as are work readiness and job opportunities. The to is aspirational, a primary motivator and may be the reason students are entering tertiary study as it provides the transition to move from where they are, to where they want to be.

\section{Challenges for lecturers}

It is fashionable to celebrate diversity, to pay lip service to creating a community of learning, to induct students into your discipline on your terms and to market our institutions as preparing students for employment. To go beyond a surface level approach to the from-with-of-to framework requires change by the institution and individuals and change in curricula and teaching. This is where the challenge lies. What does it mean for teachers to embed transition, especially for those who have their professional expertise rather than teaching as their primary identity? As academic advisors promoting transition pedagogy, we need to recognise that it presents a number of challenges to academic staff.

An additional preposition, which complements the other four, is by. This covers the interventions and activities we implement in order to ensure that the transition into tertiary study is as easy as possible. The by for teachers addresses the modes of delivery, the design of curricula and the explicit teaching of the process of enquiry which enhance the early experience, encourage engagement and lessen the mystery of tertiary study. Interventions at 
Unitec in 2012 will revolve around Assessment for Transition but there are a number of other approaches which are advocated. The bys in each of the four areas may include:

From

- run diagnostic assessments, for example, foundational or academic literacies;

- recognise the academic capital that students have, for example, Maori/Pasifika strategies.

With

- encourage the use of support services, for example, PASS, learning centre;

- create communities of learning online.

of

- identify the demands, both explicit and implicit, of the curriculum;

- be explicit about the enquiry process that is expected.

To

- work for cohesion in the program so it makes sense to students;

- make sure the graduate profile emphasises lifelong learning and being work ready;

- understand the to may be the student's greatest motivator.

\section{Conclusion}

The from-with-of-to are not watertight compartments, nor are they a linear process - each is always present. The to is on students' minds from orientation week, the from is part of their identity, and the of surrounds them in all their study. Increasingly, we are finding the framework applies to many transition situations whether it is in describing the early experience, the student life-cycle, teachers moving from their professions into teaching and even the process whereby teachers themselves transition into embedding transition pedagogy.

As academic advisors, our daily tasks are often conversations with program leaders and lecturers on how best to teach. The from-with-of-to framework provides one way of looking at issues of transition and serves as a springboard for questions about how to address challenges students face. The notion of by then puts feet on the ideas. As indicated earlier, one initiative Unitec will be targeting in 2012 is Assessment for Transition. We will be piloting this with various programs and using action enquiry to evaluate the impact. In partnership with other projects, we will be making some progress toward the third generation approach to FYE as described by Kift (2008) as something that is "holistic, systematically managed ... and student-focused" (p. 14), in short a curriculum that encompasses the from-with-of and to.

\section{Conversations}

Various points were made in the conference session in response to the framework. The from in a New Zealand context is slightly different to Australia. Given that a large percentage of Unitec's students are Maori or Pasifika, priorities for transition are often defined in terms of ethnicity. At the other end of the framework, the to is of primary importance because much of a student's motivation lies in where they are heading. Relating what they are embarking on and what they are learning now to their future career is essential.

Further, in terms of the by, the suggestion was made to view the process of transition as a cyclic rather than a linear one. Students may be at different stages of transition and a 
well defined program of induction and enhancing their experience may not meet all students' needs at a particular time. Planning interventions in acknowledgement of this may result in better transition. Other feedback indicated that the framework was useful and achieved its aim of being accessible, easily remembered, yet covering the major requirements of transition.

\section{References}

Bovill, C., Bulley, C., \& Morss, K. (2011). Engaging and empowering first-year students through curriculum design: Perspectives from the literature. Teaching in Higher Education, 16(2), 197-209. doi: 10.1080/13562517.2010.515024

Bovill, C. Morss, K., \& Bulley, C. (2008). Quality enhancement themes: The first year experience. Curriculum design for the first year. Glasgow, UK: The Quality Assurance Agency for Higher Education.

Gourlay, L. (2009). Threshold practices: Becoming a student through academic literacies. London Review of Education, 7(2), 181-192. doi: $10.1080 / 14748460903003626$

Green, A. (2007). Issues in the transition from post-16 to higher education: A review of recent literature. International Journal of Adolescence and Youth, 14, 77-91. doi: 10.1080/02673843.2007.9747994

Kift, S. (2008). The next, great first year challenge: Sustaining, coordinating and embedding coherent institution-wide approaches to enact the FYE as "everybody's business." Keynote address presented at the 11th Pacific Rim First Year in Higher Education Conference, "An Apple for the Learner: Celebrating the First Year Experience." Hobart, Australia. Retrieved from http://www.fyhe.qut.edu.au/past_papers/papers 08/FYHE2008/content/pdfs/Keynote $\%$ 20\%20Kift.pdf

Kift, S., Nelson, K., \& Clarke, J. (2010). Transition pedagogy: A third generation approach to FYE - A case study of policy and practice for the higher education sector. The International Journal of the First Year in Higher Education, 1(1), 1-20. doi: 10.5204/intjfyhe.v1i1.13

Krause, K. (2006). Transition to and through the first year: Strategies to enhance the student experience. Keynote paper Inaugural Vice-Chancellor's Learning and Teaching Colloquium 2006,
University of the Sunshine Coast, Queensland Australia.

Lea, M., \& Street, B. (1998). Student writing in higher education: An academic literacies approach. Studies in Higher Education, 23(2), 157-172. doi: $10.1080 / 03075079812331380364$

Rivers, J. (Ed.). (2005). Supporting students in tertiary study: A summary of a synthesis of research on the impact of student support services on student outcomes in undergraduate tertiary study, Wellington, New Zealand: Ministry of Education.

Tinto, V. (2009). Taking student retention seriously: Rethinking the first year of university. Paper presented at the FYE Curriculum Design Symposium 2009, Queensland University of Technology, Brisbane, Australia. Retrieved from http://www.fyecd2009.qut.edu.au/resources/SPE VincentTinto 5Feb09.pdf

Wilson, K. (2009, June). The impact of institutional, programmatic and personal interventions on an effective and sustainable first-year student experience. Keynote address presented at the 12th Pacific Rim First Year in Higher Education Conference, "Preparing for Tomorrow Today: The First Year Experience as Foundation." Townsville, Australia. Retrieved from http://www.fyhe.qut.edu.au/past papers/papers 09/ppts/Keithia Wilson paper.pdf 